\title{
Modernism and Classics: T. S. Eliot as a Critic of Goethe
}

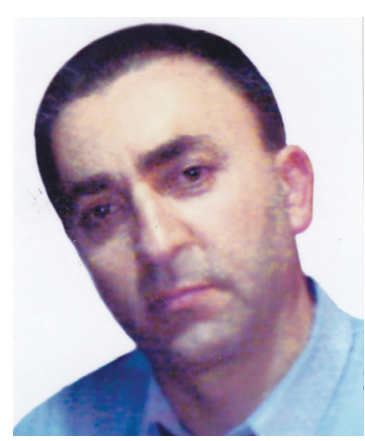

Karlen Matinyan

The greatest modern English poet and literary critic T.S. Eliot described himself as "classical in literature, royalist in politics, and Anglo-Catholic in Religion" (Eliot 1928). T.S. Eliot was one of the founders of literary trend "New Criticism" and his critical essays "Sacred Wood" (1920), "The Use of Poetry and Use of Criticism" (1933), "The Social Function of Poetry" (1943), "What is a Classic?" (1944), "Goethe as the Sage" (1955), confirmed his reputation as a great literary critic, offering a theoretical counterpart to the example of his own poetry (Ousby 1974:129).

In the present paper we will examine Eliot's modernistic view on mind and poetry. In particular we will discuss Eliot's critical outlook on Goethe's poetry.

Analyzing the connection between classical and modern literature, Eliot presents samples of classical heritage of Dante, Shakespeare and Goethe, who created their works beyond the time limits, linking the modern to the classical through Abundance, Amplitude and Unity. The curiosity of poets like Dante, Shakespeare and Goethe is the fundamental Unity. This unity is hard to define except by saying, in Eliot's words, that what each of them gives us is life itself, the World seen from a particular standpoint of a given European age and a certain man belonging to that time period (Eliot 1957).

Eliot confesses that he formerly treated Goethe's scientific theories as "amiable eccentricities" but many years later he came across Ernst Lahr's "Man or Matter", in which Goethe views were actually fostered. Pointing to the interconnection between Goethe's scientific views and his imaginative work, Lahr suggested that the same insight was struggling for outer expression in both cases. Hence, Eliot finds it unreasonable to ignore what "we accept as inspired wisdom in poetry". After getting familiar with the content of this book, Eliot changed completely his view on "Faust": if he formerly held the generally accepted opinion that Part I was more accomplished than Part II, he overturned his conclusion.

Naturally, such a "transformation" of the stance should have been publicly interpreted by Eliot himself: "Literary criticism is an activity which must constantly define its own boundaries; also it must constantly be going beyond them: the one invariable rule is, that when the literary critic exceeds his frontiers, he should do so in full consciousness of what he is doing" (Eliot, OP cit.:215).

In another comment Eliot assumes that in order to understand great poets like Goethe, a literary critic must have a solid storage of knowledge in philosophy, natural science, mythology, history. As for Goethe, one needs wisdom to plunge "into the forbidden territory of science" (Eliot OP cit.:215).

Eliot states the opinion that somehow it is easier to translate a great master's work, because even when much of the original significance is lost, "there is also more saved for more was there". This idea refers to the story, its plot and characters. "What cannot 
be translated is the incantation, the music of the words, and that part of the meaning which is the music" (Eliot OP cit.:216).

In another passage Eliot contradicts himself partly: speaking about Rilke's poetry he states that the magic of music distracts him from going deep into its sense. Anyhow, there is no doubt that "The notion of appreciation of form without content, or of content ignoring form, is an illusion: if we ignore the content of a poem, we fail to appreciate the form; if we ignore the form, we have not grasped the content - for the meaning of a poem exists in the words of the poem and in those words only" (Eliot OP cit.:225).

Eliot stresses, that he regards content "as philosophical system", as "ideas" which can be formulated in other words as a system of ideas to which there is always some possible alternative system for the reason to accept" (Eliot OP cit.:225).

Speaking highly of Goethe's poetic craft, Eliot confirms that poets like Dante, Shakespeare and Goethe can be said to belong to all Europeans. Furthermore, Eliot draws a conclusion that being one of the "greatest representatives" of their own nation, these poets promote a sense of national identity and help other nations "to understand and to accept them". As for Eliot, it's rather difficult to define how Goethe or any other great poet is associated with his own epoch and to what extent he represents it. One thing is for sure: "We are interested in Shakespeare and Goethe not only in relation to their own country, language and race, but timelessly and directly". For the genius is of importance for his own age, and yet of "permanent importance for all subsequent ages". Moreover, he can be not a typical representative of his time, not only "by being or ahead of his age, but by being above it" (Eliot OP cit.:217-218).

Speaking about the universal vein in Goethe's works, Eliot remarks that the more he studies them, the less he finds it possible to identify Geothe with his age. "I find him sometimes in complete opposition to his age, so complete perhaps as to have been greatly misunderstood" (Eliot OP cit.:218).

Anyhow, having discovered great wisdom in Goethe's art, Eliot makes the following stipulation: "It may be that there are areas of wisdom that he did not penetrate: but I am more interested in trying to understand the wisdom he possessed, than in defining its limitations" (Eliot OP cit.:220).

Admittedly, Eliot does not want to draw a distinct borderline between wisdom and poetry:

"Wisdom is an essential element in making the poetry; and it is necessary to apprehend it as poetry in order to profit by it as wisdom. The foreign reader, in absorbing the wisdom, is being affected by the poetry as well. For it is at the wisdom of poetry, which would not be communicated at all, if it were not experienced by the reader as poetry" (Eliot OP cit.:222).

Which are the characteristic peculiarities of Goethe's wisdom, so inadmissible for Eliot in his early critical essays? He came up with the idea that Goethe's wisdom is more vividly reflected in his sayings, both in prose and in verse. Interestingly enough, in his later essays he concluded that what he took for wisdom was a mere illustration to it.

Thus we may conclude that Eloit's underestimating comes from the faith that he observed Goethe's philosophy detached from his poetry. 
The last passage of his essay gives the fullproof evidence for this thought. "That Goethe was one of the wisest of men I have long admitted; that he was a great lyric poet I have long since come to recognize; but that the wisdom and the poetry are inseparable, in poets of the highest rank, is something I have only come to perceive in becoming a little wiser myself' (Eliot OP cit.:226).

These words take on a special importance if we take into account the scrutiny with which Eliot treated the language and the philosophical content of poetry, his perception and evaluation of poetic technique.

\section{References:}

1. Eliot, T.S. (1928) For Lancelot Andrews: Essays on Style and Order. www.britannica.com/

2. Eliot, T.S. (1957) On Poetry and Poets. London: Faber and Faber.

3. Mikhailov, N.N. (2006) Teoriya khudozhestvennogo teksta. M.: Academia.

4. Ousby, I. (1974) Literature in English. Cambridge: Cambridge University Press.

5. Svasyan, K. (1988) Filosofskoye mirovozreniye Gyote. Yerevan: ASRA Publication.

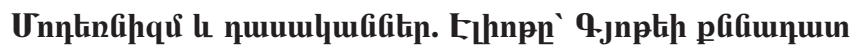

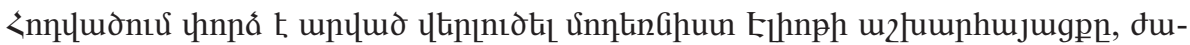

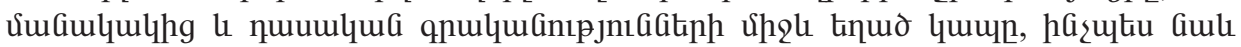

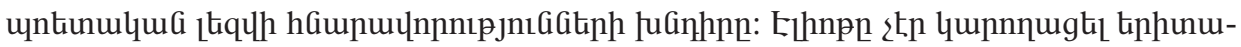

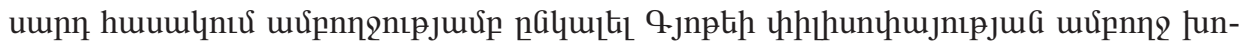

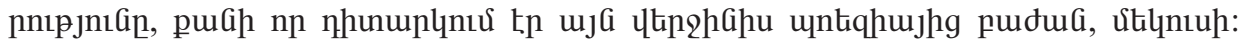

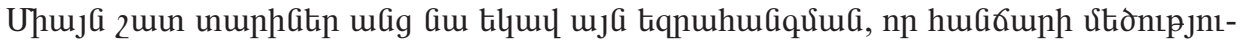

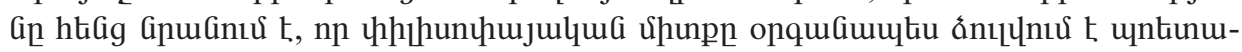

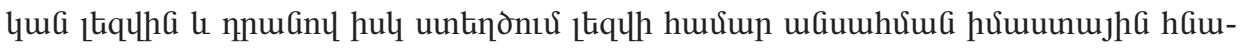
nuunnnıpjnıGitip: 